\section{CELEBRATING THE 90TH BIRTHDAY OF PROFESSOR OSCAR SHEYNIN}

ŚLĄSKI

PRZEGLĄD

STATYSTYCZNY

Nr 13(19)

Walenty Ostasiewicz

Uniwersytet Ekonomiczny we Wrocławiu

Professor Sheynin was born on November 29, 1925, in Moscow. In 1932-1942 he attended the high school, typical "ten-year" high Soviet school. In 1951 he graduated from the Moscow Institute of Geodesy. He also worked as a geodesist in the field, and taught geodesy at a geodetic technical college, was subeditor of the journal of abstracts, Astronomy and Geodesy, and a teacher of mathematics in a school. For six years he worked as a lecturer at the Plekhanov Institute of National Economy, in Moscow. In 1959 he graduated from Moscow State

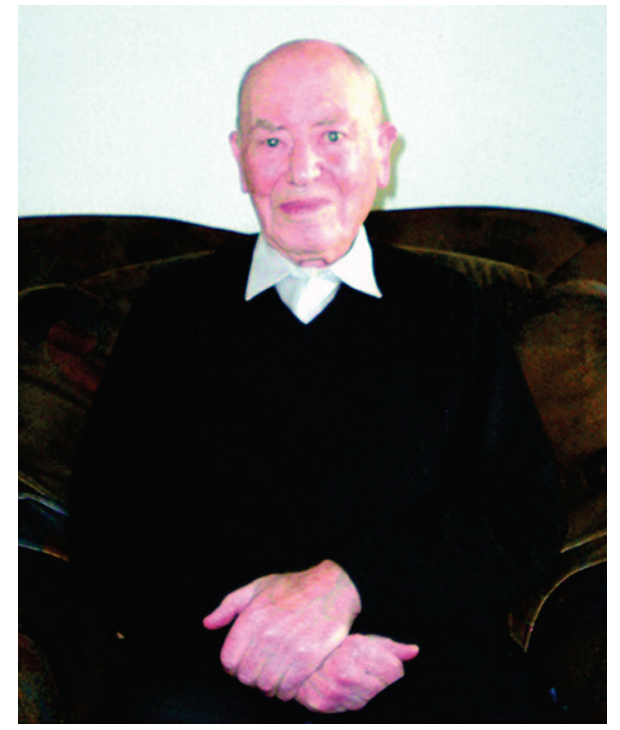
University, the Faculty of Mechanics. where he defended a dissertation about the error theory. In May 1991 O. Sheynin moved with his family (wife and the son) to Germany (Cologne, then to Berlin). Now he lives in Berlin. He has been a German citizen since 2005.

$\mathrm{He}$ works mainly as an independent researcher. His main achievement consists in a systematic description of the history of probability, of statistics together with its application to natural sciences, and of the theory of errors to the time of Kolmogorov and Fisher. Professor Sheynin made many disco-veries. These concerned Kepler; Lambert; Bayes; Daniel Bernoulli; Euler; Laplace; Poisson; Abbe; Bessel; Helmert, Lüroth; Nekrasov; and Chuprov. It is worth mentioning his study of stochastic notions in the Bible and the Talmud. 


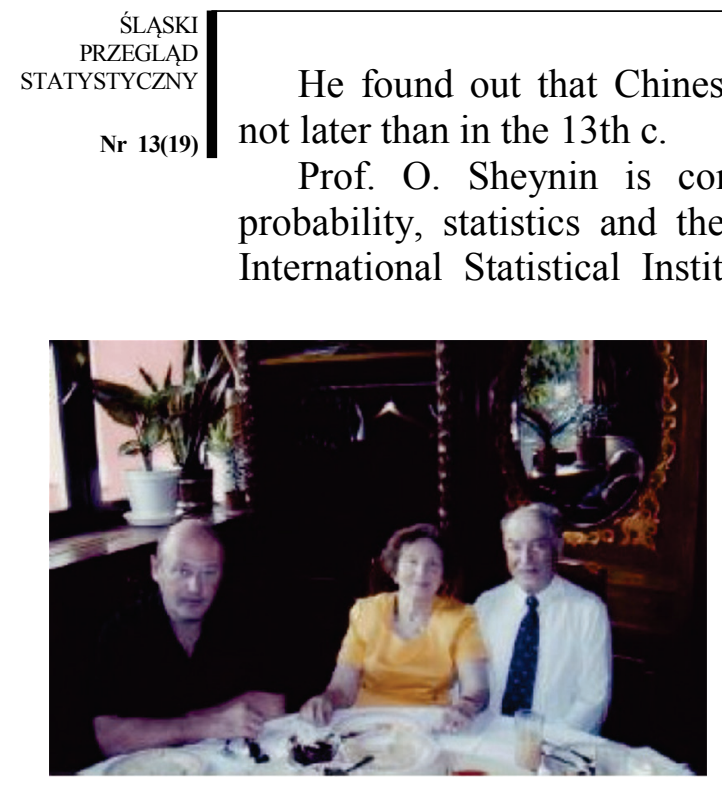

Berlin, 2001. With wife Ida (1926-2004) and son Michael (b. 1957)

1. Monographs:

- Theory of Probability. A Historical Essay (in Russian), two editions, the second (356 pages) published by NG Verlag Berlin in 2013

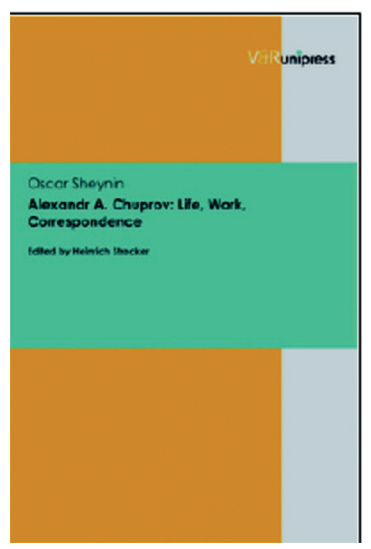

- Theory of Probability. A Historical Essay (in English), two editions, the second (271 pages) published by NG Verlag Berlin in 2009

- History of Statistics, NG Verlag, Berlin, 2012 (p. 176)

- Studies in the History of Statistics and Probability. Collected translations, Berlin, 2009, this monograph of 211 pages contains the papers translated from Russian and German into English accompanied, as usual, with valuable remarks and comments. There are five issues of these Studies

- Alexander A. Chuprov: Life, Work, Correspondence (Edited by H. Stecker)

2. Translations of entire books

- Poisson S.-D., Recherches sur la probabilite des jugements en matiere criminelle et en matiere civile, Paris, 1837. Translated into English in 2013, and into Russian in 2013 and published by NG Verlag Berlin 
- Cournot A. A., Exposition de la theorie des chances et des probabilities, Paris, 1834, translated into English and published in 2013 by NG Verlag Berlin

- Graunt J., Halley E., Nachala statistiki nasieleniya, medicisnskoy statistiki I matiematiki strahovogo dela. This book provides a translation into Russian of the classical writings of Graunt and Halley, and is supplemented by De Moivre's Preface to his Treatise of Annuites on Lives, and a fragment of Halley's letter to Hooke.

Apart from the translation, the book contains highly valuable explanations concerning the language of that period.

3. Bernoulli J., Iskustvo predpoloshenij, czasti 1-3, translation into Russian of the first three parts of Ars conjectandi, supplemented with interesting and valuable comments.

4. Thirteen volumes of Chrestomatia po Istorii Teorii Veroiatnostei $i$ Statistiki (in Russian), the first one published in 2006, and the last one in 2014.

All of the above are available on the website www.sheynin.de, copied by Google: Google, Oscar Sheynin. Home.

5. Translations of hundreds of manuscripts, papers, and parts of books, which were published in the most prestigious journals of the world, including Archive for History of Exact Sciences, Biometrika, Historia Mathematica, Jahrbücher für Nationlökonomie und Statistik, Historia Scientiarum (Tokyo), Nature, Bulletin of the International Statistical Institute, Arabic Sciences and Philosophy, Mathematical Scientist, British Journal of Mathematical and Statistical Psychology, Studies in the History of Statistics and Probability.

6. Translations into Russian of your own original works published in English

7. Hundreds of Reviews published mostly in Novye Knigi za Rubezhom, Zentralblatt MATH, Isis, Matematika 


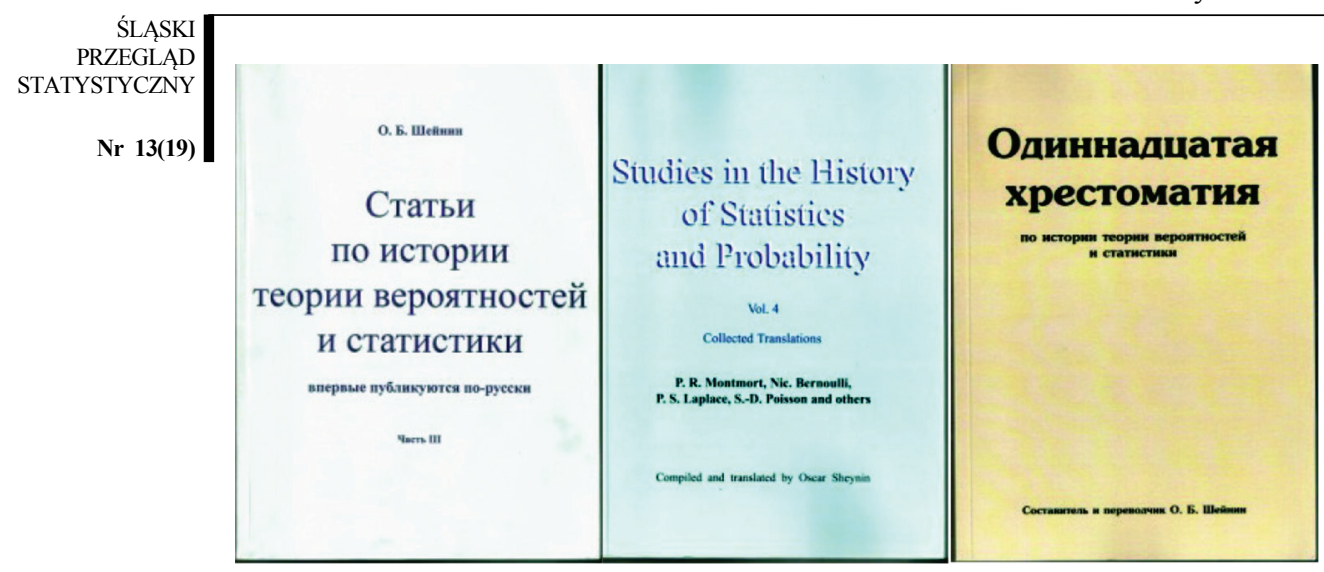

\section{Interview with Professor Oscar Sheynin}

\section{Walenty Ostasiewicz (WO):}

Dear Oscar Borisovitch, thank you very much for accepting my invitation for an interview on the occasion of your $90^{\text {th }}$ birthday.

Please accept our best wishes

Happy Birthday to You!

\section{Многая лета, Многоуважаемый Оскар Борисович!}

Astonishing is the fact that all of your publications were probably prepared without the aid of an army of secretaries and assistants. I suspect that for many years you were acting as a one-person nonprofit organization.

Is it true?

Oscar Sheynin (OS): I have been working all alone. Many books were published by a single Russian old man (NG Verlag in Berlin) in 15-20 copies. My son paid the publisher (not really much), and now I am printing the same number of copies by a Copyshop (cheaper and simpler).

WO: There were always problems with the proper spelling of Russian names. How is it in the case of your name, which originally is the following:

\section{Шейнин Оскар Борисович}

OS: Soviet authorities gave me my passport for traveling abroad and the horrible Oskar Cheinine is their way of spelling my name in French. Oskar Cheinine is their way of spelling my name in French (as it was then officially done), but Oskar is German rather 
than French so I became half German and half French. I was never happy with it.

WO: Alles ist klar! So, gehen wir weiter Professor Sheynin, you have been living in Berlin for more than 20 years, exactly 23 years, do you remember your first "visit" to this city, how was it? How long were you there? Did you speak German then?

OS: The middle parts of most wide streets were covered by neat piles of bricks from ruined houses. The U-Bahn from the Russian sector stopped at its borders. An employee of the U-Bahn at every station announced through a loudspeaker (if I am not mistaken) Aufsteigen - Zurückbleiben - and something for the third time. Perhaps Abfahren. I heard a German complaining to another man, both were waiting for a tram (I also): kein Strom und das Rathaus brennt Tag und Nacht. The Rathaus: occupied by Soviet local military authorities. German doctors were not allowed to treat Soviet military men.

WO: How long were you there? Did you speak German at that time?

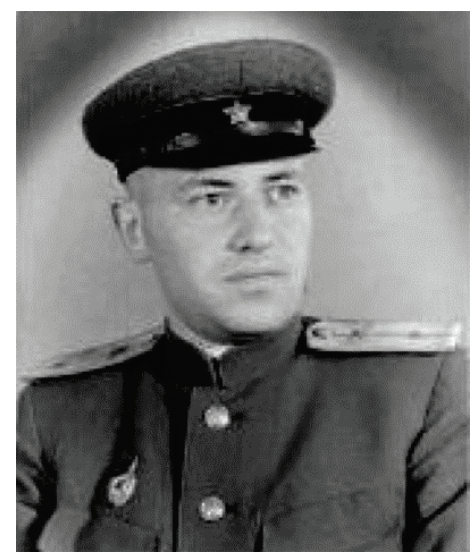

Berlin, 1946

OS: Only a few weeks. The Anglo-American school (also the German and French schools) was closed in 1936 or 1937 and I continued studying in a usual Russian school, I had to learn German (against my wishes, I thought that English was enough).

WO: You have delved into a lot of archives, probably in different countries, how much time did you spend there? Did you have any problems accessing rare manuscripts?

OS: I spent several weeks in a Moscow archive studying the Chuprov papers. I would have gladly studied in some Moscow archives but for me this is too difficult now. Some libraries had special departments, studying there was only possible after receiving special permission. (Books and periodicals considered harmful or possibly harmful). I wrote about this in my lengthy biography. I received materials from archives in Sweden, the USA and Göttingen by mail. 
WO: Before asking the next questions, let me quote a line from one of your works:

Charakterleistungen sind ebeso Wert wie wissenschftliche. In my opinion, personality is of great importance; there are people holding a title of professor but with no personality. How did it happen that without any institutional or financial support you have managed to publish so much ? Furthermore, how is that the fruits of your hard work are offered free to anyone who desires it?

OS: Studying history of math (or translating pertinent literature) is extremely pleasant for me, it is the work of my life. Money is less than secondary. My natural inclination and education caused me to study and write comprehensively. I had to teach mathematics (for a short period I worked as a geodesist).

WO: Your life was not strewn with roses, for five long years you were unemployed. Was it the communist principle, to anyone according to his needs?

OS: Stalin was The Damned and communism was responsible for all the horrible events of the $20^{\text {th }}$ century except World War I, but including the rise of militant Islam occasioned by the Soviet invasion of Afghanistan. I lived in the Soviet Union and hated its political system. Life was regulated. I was most likely suspected of being alien to the system.

WO: How did you manage to live and to work while being unemployed? Was it your decision to remain unemployed for such a long time?

OS: We had some savings and my wife continued working. I could have only worked as (say) a watchman but preferred to continue my scientific work. Much more can be found in my Russian biography (my website, document 32).

WO: Now, more about Charakterleistungen. Could you tell us about your motives behind the decision to offer the fruits of your hard work free of charge instead of selling your copyrights to some company?

OS: Over the years, I have made a few attempts to publish properly some of my materials, but unsuccessfully. The history of math is not a favourite topic for publishing houses, my work is not to their taste and no institute is backing me. One exception: my book about Chuprov, Editor: the late Prof Heinrich Strecker, a student of 
Anderson who was a student of Chuprov. Strecker told me that he felt himself to be a grandson of Chuprov.

WO: Did you type all of the thousands of pages of your works yourself? The 13 volumes of the Chrestomatia alone amounts to more than 2000 pages!

OS: Who else?

WO: If someone decide to create a pantheon of ten statisticians, and would ask you for recommendation, who would you recommend?

OS: Jakob Bernoulli, A. De Moivre, T. Bayes, D. Bernoulli, P.S. Laplace, C.F. Gauss, K. Pearson, R.A. Fisher, H. Cramér, S.S. Wilks, A. Hald. Chebyshev and a few other most eminent scholars were not really statisticians.

WO: Do you know any Pole who has significantly contributed to Statistics as a science?

OS: Ladislaus von Bortkiewicz (a Russian Pole). Sygmund Revkovskii's treatise is lost. Prof. Wieslaw was unable to find a single copy. Smoluchowski (statistical physics). Neyman who became an American scientist. He is the only one in the $20^{\text {th }}$ century whom I know about (not really much). There were others in the $20^{\text {th }}$ century.

WO: What is your opinion on the Neyman-Pearson dispute?

OS: Among the events of the $20^{\text {th }}$ century I only studied Poincaré and Markov, and partly Pearson (Karl not Egon).

WO: What do you think about the Glivenko-Cantelli theorem? In the majority of the textbooks it is considered "the main statistical theorem"? However, you did not even mention it in your history. Could you tell us why?

OS: Same reason: $20^{\text {th }}$ century.

WO: And a related question: is the name of the Gauss-Markov theorem historically correct?

OS: ... see the beginning of $\S 14.2$ of my English Theory of probability. Historical essay. Neyman invented it in 1934 but later discovered his mistake. There is no such theorem at all.

WO: You have stated that in scarcely populated branches of mathematics everyone knows almost everyone else. Do you know some historians from our late 'socialist bloc'? 
OS: I barely know historians of mathematics. In Russia Sergei

Nr 13(19) Demidov. In probability, there seems to be no one at all.

WO: You speak fluently four important languages: Russian, English, French and German. I am very anxious to know which one of them is the most suitable to express human thought?

OS: Fluently I speak English but no other language. There is an English saying Trade follows the flag. I say: Language follows science. Computer language is mostly English. In ordinary life, there should be as little borrowing from other languages as possible; the French have invented a new word for their language: Frenglish! Too bad. In 1873 Alph. DeCandolle foresaw that English will become the international language for science.

WO: The following question is related to the previous one: is it possible to translate я знаю что вертится земля ...?

OS: The Earth rotates, he knew it well, but a family man was he.

WO: Thank you very much for your time and the interesting interview. Before we end, would you like to convey any special messages for Polish readers?

OS: Read the New Testament carefully and convince yourselves in that the Devil entered Judas and actually ordered him to betray Jesus.

---in that SOME Jews demanded the death of Jesus whom they believed IN GOOD FAITH to be a dangerous heretic rather than Son of God . I sent you a manuscript in Russian and English in which I described this in detail.

WO: Thank you very much. 


\section{Excerpt from the book}

Theory of Probability and Statistics as Exemplified in Short Dictums,

Berlin 2009, ISBN 3-93817-98-6 www.sheynin.de

This book contains first-ever collection of short sayings on probability and statistics expressed by men of science.

In total, 832 sayings are arranged into 5 big groups:

1. Theory of Probability

2. Statistics and Mathematical Statistics

3. Mathematical Treatments of Observations

4. Randomness

Below are four excerpts.

1. The first concerns the origin of the notion of "Moral expectation", which plays a fundamental role in the theory of rational decision making.

2. The second one traces the emergence of the notion of errors of the first and second kind as far back as 1716 .

3. The third concerns the extraordinary women to whom the study of statistics was a religious duty, this is Florence Nightingale.

4. The fourth is about Ladislav von Bortkiewicz who was called the Pope of Statistics. 


\subsection{Moral Expectation}

115. A promet de donner un écu à $\mathrm{B}, \mathrm{si}$ avec un dé ordinaire il amené au premier coup six points, deux écus s'il amené le six [only] au second, trois écus s'il amené ce point au troisième coup ... On demande quelle est l'espérance de B. ... On demande la même chose si A promet à $\mathrm{B}$ de lui donner des écus en cette progression 1, 2, 4, 8, 16 \&c, ou 1, 3, 9, 27, \&c ... Niklaus Bernoulli, letter of 1713 to Montmort; Montmort (1713/1980, p. 402).

Comment. In 1738, Daniel Bernoulli studied this game (No. 116). He published his memoir (and many others) in Petersburg, hence the name of the game. Its conditions were insignificantly changed: the progression $1,2,4, \ldots$ persisted, but the die was replaced by a coin. On the further history of the game see Sheynin (2009a, § 3.3.4). In particular, Freudenthal (1951) recommended to consider a series of such games with the role of the gamblers in each of them to be decided by lot.

116. No characteristic of the persons themselves ought to be taken into consideration; only those matters should be weighed carefully that pertain to the terms of the risk ( $(2)$. But anyone who considers the problem with perspicacity and interest will ascertain that the concept of value which we have used in this rule may be defined in a way which renders the entire procedure universally acceptable without reservation. To do this the determination of the value of an item must not be based on its price, but rather on the utility it yields (§3).

In many games, even those that are absolutely fair, both of the players may expect to suffer a loss; indeed, this is Nature's admonition to avoid the dice altogether (\$13). D. Bernoulli (1738, $\S \S 2,3,13$; translation 1954).

Comment. This was the author's starting point which led him to the introduction of the concept of moral expectation; the term itself was introduced in 1732 by Gabriel Cramer in his letter to Niklaus Bernoulli and quoted by Daniel. The immediate cause of Daniel's studv was the Petershuro naradox. see No. 115 


\subsection{Administration of Justice}

341. The witness [in law-suits pertaining to loans] to whom, within seven days after he has given evidence, happens [a misfortune through] sickness, a fire, or the death of a relative, shall be made to pay the debt and a fine. Bühler (1886, § 108).

Comment. This is an early statement actually concerning errors of the first and second kind. The words in brackets were added by Bühler.

342. Laplace rejeté les résultats de Condorcet, Poisson n'a pas accepté ceux de Laplace; ni l'un ni l'autre n'a pu soumettre au calcul ce qui y échappe essentiellement: les chances d'erreur d'un esprit plus ou moins éclairé, devant des faits mal connues et des droits imparfaitement définis. Bertrand (1888a, p. 319).

Comment. Since he mentioned droits, Bertrand apparently had in mind civil cases. Suchlike entirely negative, and sometimes even wrong statements (as in this instance) were characteristic of Bertrand, see NNo. 120, 365, 737.

343. Any one of us would prefer to pass a sentence acquitting a wrong-doer rather than condemning as guilty one who is innocent ... Aristotle, Problemata 951b0.

344. Viel besser ist, zehen schuldige zu befreuen, als einen unschuldigen zum Tode zu condemniren. Russia's KriegsReglement (1716/1830, p. 403).

345. [In accord with the idea of Laplace [1816/1886, p. 521], as Poisson remarked, there should be] plus de danger pour la sûreté publiques à l' acquittement d' un coupable, que de crainte de la condemnations d'un innocent ... Poisson (1837, p. 6).

346. Il est manifeste que les conditions de majorité, de pluralité imposées aux décisions d'un corps judiciaire ou d'une assemblée délibérante, doivent avoir des relations avec la théorie mathématique des chances. Cournot (1843, § 192). 
PRZEGLAD STATYSTYCZNY

Nr 13(19)

\subsection{Application in Science; General Considerations}

403. Her [Nightingale's] statistics were more than a study, they were indeed her religion. For her Quetelet was the hero as scientist, and the presentation copy of his Physique sociale is annotated by her on every page. [She] believed - and in all actions of her life acted upon the belief - that the administrator could only be successful if he were guided by statistical knowledge. The legislator - to say nothing of the politician - too often failed for want of this knowledge. Nay, she went further; she held that the universe - including human communities - were evolving in accordance with a divine plan; that it was man's business to endeavour to understand this plan and guide his actions in sympathy with it. But to understand God's thoughts, she held, we must study statistics, for these are the measure of His purpose. Thus, the study of statistics was for her a religious duty, pp. $414-415$.

509. Bortkiewicz had a photographic memory and knew the literature on practically any topic of economics and statistics. ... And he had a philosophy of statistics that he had never developed in his writings. For him statistics was not a body of mathematical formulas and techniques but the art of quantitative thinking. An outstanding mathematical statistician, he liked to play with formulas and had published many articles full of algebra, but this was more or less a game; very often the purpose of his mathematical essay was to prove the futility of mathematics. To him the essence was to use measurement to obtain a better understanding of facts of life. ... In Germany, he was called the Pope of statistics.... The publishers have stopped asking [him] to review their books [because of his deep and impartial response]. ... [He was] probably the best statistician in Europe. ... [Bortkiewicz' statement:] I do not review the work of persons I know and I don't care to meet authors whose work I have to appraise. Woytinsky (1961, pp. $451-452)$.

510. Für diese [for the Berlin University, Bortkiewicz] beinahe wie ein "Fremdkörper" geblieben ist, welcher sich in den Betrieb und die Traditionen einer deutschen nationalökonomischen Fakultät nicht recht einzuordnen vermochte. Anderson (1932, p. 246/1963, p. 534).

Comment. Bortkiewicz worked at the Philosophical Faculty of that University.

511. Bortkiewicz schrieb nicht für die weite Öffentlichkeit und war durchaus kein guter Popularisator seiner eigenen Ideen. Er stellte ferner sehr hohe Ansprüche an die Vorbildung und Intelligenz seiner 